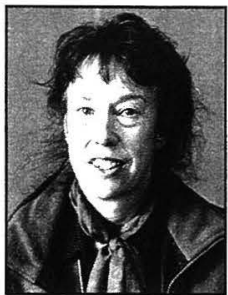

\section{SOLO PARENTS: MOTHER-WORK AND/OR OTHER WORK? \\ LIBERAL, CONSERVATIVE AND SOLIDARISTIC POLICIES}

\author{
Celia Briar \\ Social Policy and Social Work, \\ Massey University
}

\begin{abstract}
In recent years, New Zealand has been following the American lead in expecting solo parents (in practice mainly mothers) to move off state benefits and rely upon a combination of their own earnings from paid employment plus contributions from the absent parent. However, whilst this policy direction is fast becoming the greater norm in the 'residual' welfare states of the English speaking nations, there are greater variations in Europe. For the purposes of this paper, three broad classifications in welfare policy towards mothers are used: liberal (prioritising individual responsiblity), conservative (a focus on family and community responsibility) and solidaristic (state/collective responsibility). These are of course 'ideal types', and the welfare policies of all nations examined contain elements of all three approaches to welfare. The paper assesses the extent to which each of these approaches provides solo mothers with genuine options regarding paid / unpaid work, and freedom from poverty.
\end{abstract}

Keywords: solo parents, welfare, gender, poverty

In recent years, New Zealand has been following the American lead in expecting solo parents (mainly mothers) to move from state benefits to reliance upon their own earnings plus contributions from the absent parent. However, whilst this policy direction is intensifying in the 'residual' welfare states of the English speaking nations, there are greater variations in Europe. For the purposes of this paper, three broad classifications in welfare policy towards mothers are used: liberal (prioritising individual responsibility), conservative (a focus on family and community responsibility) and solidaristic (state/collective responsibility) ${ }^{1}$. In fact these are only tendencies, and the policies of 'welfare capitalist' nations contain elements of all three approaches. This paper assesses the extent to which each of these tendencies provides solo mothers with genuine options regarding paid and unpaid work, and freedom from poverty.

\section{'Liberal' welfare regimes}

'Liberal' policies are those which are based upon a belief in individual liberty, choice and equality of opportunity. Mothers are portrayed as having the same rights, opportunities and obligations as men. However, obstacles to mothers achieving equality in the public sphere are largely overlooked, and the state does not play a major part in reducing inequality in paid and unpaid work. 'Incentives' for mothers to engage in paid work are created by cutting and tightening benefits and benefit regulations. Governments dominated by liberal right views include the Clinton and Blair administrations in the USA and UK respectively, and the current New Zealand government, led by Jenny Shipley.

\section{'Work testing' solo mothers}

In the United States, Britain and increasingly in New Zealand and the other English speaking nations, welfare policies in the 1990's aim to reduce 'dependency' (on benefits) by pressuring 'unsupported' mothers (mainly single, separated, divorced, or widowed women) on state benefits to become 'independent' through paid work. In New Zealand, however, the wives of unemployed men are now also being 'work tested'. The degree of pressure to find a paid job (for example the age of the youngest child) varies from country to country and state to state. In general, however, unpaid childcare at home is increasingly no longer regarded as a sufficient reason for state support of low income women.

The Wisconsin Works programme in the United States was one of several experiments in which Aid for Families with Dependent Children (AFDC) was discontinued and states given a block grant of funding instead (Waldfogel, 1996:2). Under this programme, mothers are required to move into full time paid employment or workfare when their babies are twelve weeks old. In Canada, 'adults', including mothers, are expected to be in full time employment. In the $\mathrm{Ca}$ nadian state of Alberta, a mother is considered 'employable' once her youngest child is six months old (Baker, 1998: 31). In New Zealand, mothers of children over 16 years old were expected to be available for work before 1996, but age has since been progressively lowered, and workfare introduced from October 1998. The UK Labour government's New Deal is aimed at lone parents with school age 
children (McDermott, Garnham and Holtermann, 1997:7). However, in 1998 benefits for British solo parents were cut, to give them an 'incentive' to move into paid work.

In order for mothers to become self supporting, enough adequately paid jobs must actually exist (Gilbert, 1991). However, 'liberal' economic policies have vastly reduced permanent full time employment. Women are more than twice as likely as men to be casual workers (Brosnan and Walsh, 1998: 38-9). 'Jobs' may mean being on-call with no guaranteed hours, and incomes too low and unreliable to meet the costs of maintaining a home and dependents.

\section{Childcare}

Shortages of affordable good quality child care are a feature of the 'liberal' English speaking nations (Bradshaw and Millar 1990:456). Childcare is provided as part of the Wisconsin Works programme, but places are not free, even to families on the lowest incomes. Provisionally licensed child care centres cost less to the parent, but standards are lower, as staff may be completely untrained. In the UK most of the growth in childcare has been in the private and voluntary sector, where parents have to meet the full costs; and where the pressure to reduce costs compromises the quality of service that can be offered (McDermott, Garnham and Holtermann, 1997: 25). Many mothers have to work weekends or shifts, which compounds their childcare problems. Overall, many mothers have less time for their children and little, if any, more money. In the US, there have been increased state subsidies for childcare, but this has been insufficient. The costs of subsidising childcare sufficiently to enable mothers to go out to work, without becoming even poorer, are huge (Waldfogel 1996:1).

Despite their emphasis on 'getting mothers back to work', the USA, Australia, New Zealand and UK also have the weakest maternity leave provisions. A supportive parental leave scheme makes it easier for mothers to return to their previous job in the paid work force (Bradshaw et al 1996:30-1)

\section{Welfare cutbacks}

As part of the drive to push welfare mothers into the paid workforce, benefits have been cut in New Zealand, the United States and Britain. In New Zealand, as a result of the 1991 social policy changes that reduced benefits and increased housing rentals, the poorest $20 \%$ of households lost around 24\% of their income (Jobs Letter, August, 1998). Lone mothers are bearing the brunt of welfare cutbacks. In the process the well being of children appears to have been overlooked (Land and Lewis, 1997:55). According to Maria Cancian and Linda Gordon:

"....Two-thirds of AFDC recipients are children, and they are almost completely forgotten in the welfare debate.... Welfare currently gives too little to provide adequately for their children; welfare 'reformed' will generally give them even less."

(Cancian and Gordon, 1996).

\section{The feminisation of poverty}

Solo mothers' rates of full time employment in the UK and New Zealand are low at only $17 \%$ : comparable with the 'conservative' Holland at 16\% (Bradshaw et al 1996:57). However, moving into paid work does not necessarily lift mothers and their children out of poverty. Japan has very high rates of employment amongst solo parents $(82 \%)$ (Bradshaw et al 1996: 57), but also of working poverty (Peng, 1997). American mothers who succeed in obtaining private employment may be no better off, as the creation of low paid 'workfare' jobs drives general wages lower.

The feminisation of poverty has been greater in the USA than in Europe: lone mothers' poverty has accounted for much of this (Casper, McLannahan and Garfinkel, 1994). In the UK the vast majority of solo mothers and their children are living in poverty (Land and Lewis, 1997:17). The USA also has the highest level of inequality of the countries studies by Hobson( 1990: 240).

Solo mothers have needed to earn well above the average female full time wage to make it worthwhile ceasing to claim supplementary benefit (Land and Lewis, 1997:29 and 36; Joshi 1991). This is because women's wages have generally been too low to compensate for losing subsistence-level benefits. Because of this, 'less eligibility' (making welfare recipients worse off than employees) cannot be applied to most mothers and children without imposing hardship. Earlier in the twentieth century, policies did not encourage mothers to be self supporting, and so it was not unusual for state benefits for women to be higher than women's wages (Briar, 1997). Now that mothers are expected to go out to work, policies will have to recognise that women's wages are not adequate to support solo parent families.

\section{Summary}

The drive by 'liberal' policy makers to move solo mothers into paid work is problematic for solo mothers and their children, who become separated but remain poor. However, the policy is not problem-free for governments either. In order to be seen as even remotely 'successful' in getting lone mothers into employment, governments have to spend more on childcare and employment creation: a more expensive option than providing mothers with an allowance to remain at home.

\section{The conservative right and welfare policy}

Although the English speaking nations such as New Zealand, led by the USA, have been pressuring solo mothers into the paid work force (Baker, 1998:31), this is not the case everywhere. 'Conservatives', also known as the 'moral right' hold that women, including solo mothers, ought to give priority to their family responsibilities. Conservative policies discourage mothers' paid employment through inadequate child care provision and through benefit regulations; al though some conservative regimes make a distinction between partnered and solo mothers. Benefits which cease when a mother moves into paid employment create a disincentive for mothers to engage in paid work: as a result 
of such policies solo mothers' labour force participation is low. Examples of conservative polices towards mothers are to be found in nations such as Germany, Switzerland, Ireland and The Netherlands (McLaughlin and Rogers, 1997; Klett-Davies, 1977); but also within the English speaking countries, where, as we see below, conservative policies exist alongside liberal ones, often in harmony but sometimes in tension ${ }^{2}$.

The moral right's 'family values' and their relationship with liberalism

In general marriage is regarded by the moral right as the foundation of a good society (Michel, 1998:51), and solo mothers are seen as undermining this institution. Solo mothers have been blamed for high public spending on benefits, raising criminal sons and allowing fathers to escape their responsibilities (MacDermott, Garnham, and Holtermann, 1998). In the USA, the 'moral right' agenda of the Republicans to end illegitimacy and family breakup has resulted in modifications of Clinton's liberal programme (Waldfogel, 1996: 12).

The right wing critique of welfare benefits for solo mothers rests partly on the assumption that benefits encourage marriage breakdown and lead to dependency on the state (George, 1996b:190) ${ }^{3}$. This also fits with liberal right residualism. Financial dependency of women on men, still regarded as desirable by the moral right, is also implicitly condoned by the liberal right, in that there is no 'work test' for mothers with partners capable of supporting them; and the 'cohabitation' rule is still inuse in benefits administration in the English speaking nations (Pascall, 1997: Baker, 1998:10-12). Another example of overlap between the liberal and moral right is the continuing expectation that non custodial parents (mainly fathers) must provide financial support.

However, another element of conservative thinking is the idea that mothers should be resourced to stay at home with their children. This is where the paths of the liberal and conservative right diverge. Although associated with conservatism, benefits to allow mothers to stay at home have been an important means of avoiding extreme poverty. For example, solo mothers in The Netherlands are entitled to a social minimum of 90 per cent of the minimum for a married couple, and their rate of poverty is low (Sainsbury, 1996:77-8). In the USA, Aid for Families with Dependent Children (AFDC) and the New Zealand Domestic Purposes Benefit and widows pensions were originally designed to allow unsupported mothers to stay at home with their children (Waldfogel 1996:3; Gauthier, 1996: 165). The stigma attached to unmarried motherhood and divorce declined in the 1970 's partly because of the women's movement drawing attention to domestic violence (Land and Lewis, 1997:2). Provided that mothers refrained from (hetero) sexual relationships, the state took the role of breadwinning husband to unsupported mothers, even in the residual states of America, Britain and New Zealand.

Some conservative writers in English speaking countries argue that paying benefits to allow solo mothers to remain with their children is preferable to their leaving their children in day care (Morgan, 1996). This argument is not confined to conservatives. Some feminists argue that because many solo mothers experience poverty and discrimination in the paid workforce, they should be allowed to raise their children on a benefit if they so choose (Mink, 1998).

\section{The moral right and childcare}

Child care is not generally favoured by conservatives. For example, in Who Needs Parents? (1996) Patricia Morgan argues for caregiving by mothers in preference to day care, preschool education, au pairs and care by fathers. She argues that even solo mothers should be allowed to stay at home, on the grounds that children, especially boys, are harmed by poor quality childcare. Conservative nations, and conservative influences within 'liberal' nations tend to oppose large scale provision of child care other than that provided by mothers.

\section{Advances made by the conservative (moral) right}

In the USA, several states are trying to reduce the prevalence of solo motherhood. 'Family caps', where 'welfare mothers' who have another child receive no additional benefit (MacDermott, Garnham and Holtermann, 1998: 9) had already been introduced by July 1996 in Arkansas, Georgia, Indiana, Virginia and Wisconsin (Waldfogel, 1996). However, they do not prevent solo motherhood. States have also been given financial incentives by the federal government to run sexual abstinence programmes, aimed at reducing births outside marriage without increasing abortions; and lone motherhood is made so grim that solo mothers may lose their children to fostering or adoption (Kittay, 1998:33 and 41). Ironically, the financial difficulties created for women by the policies are causing increasing numbers of mothers to enter prostitution, one of the few occupations in which unsupported mothers can provide both care and financial support for their children, although this may cost them custody of their children (Briar and Matthews, 1998).

In the USA, the Personal Responsibility Act of 1996 introduced benefit cuts of $25 \%$ if a woman did not name the father of her child(ren). Aggressively enforcing absent fathers' contributions has been another example of 'moral right' thinking which has characterised the English speaking nations (Baker, 1998:32), although it has been relatively unsuccessful. Even if there was perfect enforcement this would only reduce women's poverty very slightly, as the earnings of most of the men are relatively low (Waldfogel 1996:10) and claiming money from ex-partners can raise problems for mothers (Bradshaw and Millar 1990:447). Nevertheless, families, especially estranged fathers, are increasingly expected to provide welfare where the labour market fails to produce adequately paid jobs.

About 20 states in America also penalise parents whose children truant from school. Others reduce benefits to parents whose children are not up to date with their immunisations (Waldfogel 1996:20). Both these policies were also 
suggested in the 1998 New Zealand document Towards a Code of Social and Family Responsibilities.

\section{Limitations to the success of the 'moral' right}

In the USA, 'moral right' 'family values' initiatives have been unpopular, and polls showed that they were approved of by only 15 per cent of voters, whereas most Americans believe that solo mothers should go out to work (Waldfogel, 1996: 26-7). The U.S. Personal Responsibility Act of 1994 occurred when the Republicans took control of Congress, and was to have required states to institute policies such as ending benefits to teenage mothers, for children born to women on AFDC and mothers who did not disclose the father of their child. However, the lack of support for the 'moral' right ideas meant that these elements of the Act were not adopted in practice (Ibid 12-13), whereas the part introducing the 5 year lifetime limit to benefits irrespective of need was retained.

The moral right expect women and children to become once again dependent upon men, but fail to take account of the changes that have taken place in family structure. Lone parenting has become an established and widespread family form; and there has been a separation of sex, and marriage and parenthood (Land and Lewis, 1997: 5-12; Drew, 1998: 22-3). Further, large numbers of men now earn too little to support a family.

\section{Summary}

The conservative, or 'moral' right attempt to reimpose 'traditional' family forms and gendered divisions of paid and unpaid work. Nevertheless, some 'conservative' regimes enable mothers to remain at home with their children in relative comfort. For example, in The Netherlands, the level of income transfers for at-home mothers keeps most mothers out of poverty (Hobson, 1994). To some feminists, this is an attractive option. For example Mink (1998) argues that for poor women paid work has been an additional burden rather than a source of liberation. However, the difficulty with paying mothers on condition that they remain at home may be another denial of choice.

\section{'Solidaristic' welfare states}

'Solidaristic' policies for the purposes of this paper, are those which promote inclusion, interdependence, mutual responsibility, shared action and shared risks (Spicker:1991:17). Such policies tend to assume that children are an asset and a responsibility of the whole nation, not just of the parents. They therefore compensate mothers for the work of child bearing and rearing whether or not they also go out to work. These also tend to exist alongside policies for the promotion of greater gender equality in paid work, which although incomplete, are still more advanced than in the nations with residual welfare states.

\section{Solidarity in policy}

Solidarity is where the rich express solidarity with the poor through redistribution by paying taxes to fund benefits. The concept has widespread support in France, Denmark, Sweden and Norway. However, elements of the concept have been present in the UK, for example in the post war acceptance of the recommendations in the Beveridge Report. In New Zealand an equivalent acceptance of solidarity was the 1938 Social Security Act. Solidarity promotes community, social cohesion and integration, and overcomes marginalisation. It is a way of overcoming stigma (for example towards solo mothers) (Spicker, 1991: 26-7). Child benefits are more generous because of the principle of solidarity in France, Holland and Belgium. In France, benefits for 'orphaned' children (later becoming a single parents' allowance) have been paid primarily in the interests of the child and to help prevent a decline in the birth rate, but are nevertheless of considerable support to solo mothers (Lefeaucheur and Martin, 1997: 225-6). The benefits assist mothers to stay home with their children before they enter nursery school at the age of three, and are intended to help the mothers of older children to move into paid work.

\section{Labour force participation}

Rates of employment (full and part time combined) are much higher in France (82\%) and Sweden (70\%) than in either the 'liberal' or conservative' states (Bradshaw et al 1996: 57). A high proportion of Swedish mothers work part time, and are more likely to work in the public sector (Bryson, 1992; Langham and Ostner, 1991: 134-5). However, in Sweden 'part time' usually means 20-34 hours per week (Bjomberg, 1997: 244). Attempts have been made in Swedish social policy not to stigmatise lone mothers. Nevertheless, discrimination against them by employers does occur. Research shows that solo mothers have a stronger orientation towards paid employment than married mothers, but have been more severely affected by rises in unemployment in the 1990's (Bjomberg, 1997: 242-251). Nevertheless, Sweden facilitates women's entry to the paid workforce as well as minimising the cost to women of childbearing and rearing (Drew, 1998:14). The major factor affecting mothers' participation rates is the availability of quality affordable childcare (Bradshaw et al, 1996:32).

\section{Childcare}

The provision of early childhood care and education conveys the message that the nation as a whole wishes to take a share in the costs of raising the next generation (Spicker, 1991:28-9). In Sweden, Denmark, and France, childcare is provided on a major scale, and is geared to both the requirements of working parents and the educational needs of the child (Bryson, 1992: 210). Children of solo mothers have priority access to childcare in Denmark, Greece, France, The Netherlands, Sweden, Finland and Norway (Bradshaw et al 1996: 32; Bjornberg, 1997:252) but not in the USA, Australia, New Zealand or UK. In addition, the most supportive parental leave provisions are found in Sweden, Denmark and Norway (Bradshaw et al 1996:30-1).

\section{Levels of poverty}

Poverty amongst non-employed solo mothers is much lower in Denmark (12\%) Finland (18\%) and Sweden (10\%) than 
in the English speaking nations, where there are high levels of poverty amongst solo mothers in the USA ( $85 \%$ ), the UK ( $80 \%)$ and Australia (71\%). Poverty amongst employed solo parents in Sweden is only 1\%, in Denmark $4 \%$ and in Finland $2 \%$. Norway. By contrast, the poverty rate of employed solo parents is $30 \%$ in the USA, $27 \%$ in the UK, and $22 \%$ in Australia (Bradshaw et al 1996: 9). In other words, solidaristic nations, where there are more generous social security systems, also have less 'working poor' as well as fewer poor people on benefits.

\section{Summary}

In the Scandinavian nations, mothers have a high level of labour market participation but are also compensated for child bearing. A high level of 'solidaristic' income transfers raises most solo mother out of poverty, whether or not they choose to leave their children and go out to work. However, countries adopting these principles have higher rates of employment than most nations with liberal or conservative welfare states. This suggests that the existence of relatively generous benefits, particularly if some of them can be retained when a mother moves into paid work, seem to act as an incentive to paid work, not the reverse as is commonly believed in the 'liberal' nations. However, other factors are the existence of better paid jobs and the provision of affordable quality childcare.

\section{Conclusions}

The welfare states of the English speaking world are classed as 'liberal' in their policy directions and yet contain many conservative features, such as the shortage of quality affordable childcare (Bradshaw et al, 1996; Baker, 1998; Michel, 1998), the fact that benefits cease as the recipient begins work and the fact that mothers also lose benefits if they become sexually involved with a man seen as capable of financially supporting them. Governments in the English speaking world have always been ambivalent towards the employment of lone mothers (Briar, 1997; Land and Lewis, 1997:20). Policy in the 1990s appears to have granted earlier feminist demands for women's 'right to work' but this consists of forcing solo mothers into low paid jobs without providing the supports which would make this a realistic option. Overall, the Anglo nations share so many features of conservative welfare states that there are grounds for wondering whether their governments genuinely wish to promote the 'independent' employment of solo mothers, or whether in fact they are simply punishing women who have had children and are not financially dependent on a man ${ }^{4}$.

\section{Alternatives}

Mothers' difference in caregiving responsibilities should be recognised in social policy (Baker, 1998:32), as in the more 'solidaristic' welfare states of France and Sweden. It would be of great assistance to mothers in New Zealand if the existing welfare benefit (DPB) was reclassified as a caregivers' allowance and made unconditional, and the universal child benefit was restored (Briar, 1998). Mothers could have genuine choice over whether to seek paid work or whether to devote their time to their children. In short, motherwork should be recognised as work; and mothers themselves regarded as the experts as to when is the best time to leave their children and for how long.

Solo mothers would also benefit from educational and training opportunities. In New Zealand one of the most successful policies of the Department of Social Welfare has been to assist mothers on benefits in obtaining university degrees. However, mothers also require affordable quality childcare, family friendly hours and good pay and conditions in paid work (McDermott, Garnham and Holtermann, 1997).

Solo mothers will require this range of supports, especially childcare, if they are to become 'independent' through paid work (Michel, 1998). Further, mothers' disadvantage in the paid work force needs to be recognised and addressed. In the UK and New Zealand, part time employment is seen as acceptable for mothers, including solo mothers. However, whilst this allows women to spend more time with their children than is the case in Canada and the USA, part time employment in New Zealand and similar nations is normally 'dead end' and too low paid to provide independence. The terms and conditions of part time employment will have to be addressed if it is to be as acceptable an alternative as it is in Sweden.

We have seen that in the USA, UK, New Zealand, Australia, Canada and Japan, 'liberal' policies, far from providing equality, freedom and choice for mothers, are driving them into seeking paid work which may not exist, or is insufficient to raise them and their children out of poverty; often before they are ready to leave their children ${ }^{5}$. The rhetoric is that mothers are responsible for choosing ways of promoting their own welfare. 'Conservative' policies by contrast do not pretend to provide choice. They treat mothers as home-based economic dependents and caregivers rather than as paid workers, even though, paradoxically, they may provide a degree of independence for women leaving relationships. The third way is that of solidaristic policies, which are the most successful in eliminating poverty, and give mothers the greatest choices regarding motherwork and other work.

\section{Future Research}

More research is needed on the potential of adapting solidaristic policies, within 'liberal' nations as well as New Zealand.

\section{Notes}

1. This adapts and modifies the classifications used by Gosta Esping-Anderson (1990) in Three Worlds of Welfare Capitalism.

2. For example, in 1997 Patricia Morgan was contracted by the New Zealand Business Roundtable to conduct a year long study of families and family policy, even though her strongly held belief that mothers should stay at home was and is in contradiction with government policies of 'hassling' solo mothers into seeking paid employment. 
3. The assumption that generous state benefits will cause the breakdown of mariages and out of wedlock births is not supported by the statistics on proportions of solo parent families. In Sweden and France, where the existence of solo parent benefits and child care make it easier for a woman to leave a relationship there is a much lower rate of lone parenthood than in the USA, where access to benefits is very restricted (Bradshaw et al 1996:12).

4. Nevertheless, despite all the rhetoric in favour of marriage, social policy in the USA does not provide support for children in two parent families either (Michel, 1998:51). The same is true of New Zealand (Stephens, 1998) which has fallen short of the United Nations Convention on the Rights of the Child (Article 27), which states that children have a right 'to a standard of living adequate for their physical, mental, spiritual, moral and social development' and that governments shall take all appropriate measures to assist parents and others responsible for the child to implement this right (McDermott, Garnham and Holtermann, 1997:5).

5. There is evidence that most solo mothers want to return to paid work when they feel that it is in their children's interests (Lister, 1994:42).

\section{References}

Baker, M. (1998) Poverty, Social Assistance and the Employability of Low Income Mothers: Cross-National Comparisons Montreal, McGill/HRDC.

Bjornberg, U. (1997) Single Mothers in Sweden: Supported Workers who Mother, in S. Duncan and R. Edwards (eds) Single Mothers in an International Context: Mothers or Workers? London, UCL Press. pp 241 268.

Bradshaw, J., Kennedy, S., Kilkey, M., Hutton, S., Corden, A., Eardley, T., Holmes, H. and Neale, J. (1996) The Employment of Lone Parents: a Comparison of Policy in 20 Countries London, Family Policy Studies Centre.

Bradshaw, J and Millar, J. (1990) Lone Parent Families in the UK: Challenges for Social Policy, International Social Security Review, 43, 446-459.

Briar, C. (1997) Working for Women? Gendered Work and Welfare Policies in Twentieth Century Britain London, UCL Press.

Briar, C. (1998) Towards UBI: The Case for a Universal Child Benefit, in C. Briar and G. Gill (eds) Work, Families and the State: Problems and Possibilities for the 21st Century Palmerston North, Social Policy and Social Work, Massey University. pp 33-35.

Briar, C. and Matthews, L. (1998) Whores or Responsible Mothers? Social Policy, Social Responsibility and the Sex Industry, Presentation given to the Social Policy and Social Work Research Seminar Series, July 21 1998, Massey University, Palmerston North.
Brosnan, P. and Walsh, P. (1998) Employment Security in Australia and New Zealand Labour and Industry 8, 3, 23-41.

Bryson, L. (1992) Welfare and the State: Who Benefits? Basingstoke, Macmillan.

Cancian, M. and Gordon, L. (1996) Making Mothers Work, Dissent, Fall 1996.

Casper, L., McLannahan, S. and Garfinkel, I (1994) The Gender-Poverty Gap: What Can We Learn for Other Countries? American Sociological Review 59, 594-605.

Drew, E. (1998) Re-conceptualising Families, in E. Drew, R. Emerek and E. Mahon (eds) Work and the Family in Europe London, Routledge.

Hobson, B. (1990) No Exit, No Voice: Women's Economic Dependency and the Welfare State, Acta Sociologica 33,3 .

Hobson, B. (1994) Solo Mothers, Social Policy Regimes and the Logic of Gender, in D. Sainsbury (ed.) Gendering Welfare States London, Sage.

Jobs Letter, August 1998, New Plymouth.

Joshi, H. (1991) Obstacles and Opportunities for Lone Parents in Great Britain, in Lone Parent Families: the Economic Challenge, Paris, OECD.

Kittay, E. F. (1998) Dependency, Equality and Welfare, Feminist Studies, 24,1, 32-43.

Klett-Davies (1997) Single Mothers in Germany: Supported Mothers who Work, in S. Duncan and R. Edwards (eds) Single Mothers in an Intemational Context: Mothers or Workers? London, UCL Press. pp 179216 .

Land, H. and Lewis, J. (1997) The Emergence of Lone Motherhood as a Problem in Late Twentieth Century Britain WSP/134 London, LSE/STICERD

Langham, M. and Ostner, I. (1991) Gender and Welfare, in G. Room, (ed.) Towards a European Welfare State? Bristol, SAUS.

Lefaucheur, N. and Martin, C. (1997) Single Mothers in France: Supported Mothers and Workers, in S. Duncan and R. Edwards (eds) Single Mothers in a International Context: Mothers or Workers? London, UCL Press. pp 217-240.

Lister, R. (1994) She has other duties. Women, Citizenship and Social Security in S. Baldwin and S. Falkingham (eds) Social Security and Social Change London, Harvester Wheatsheaf.

MacDermott,T., Garnham,A. andHoltermann, S. (1998) Real Choices: a Manifesto for Lone Parents and their Children London, Child Poverty Action Group.

McLaughlin, E. and Rodgers, P. (1997) The Republic of Ireland: Mothers, not Workers, in S. Duncan and R. Edwards (eds) Single Mothers in an Intemational Context: Mothers or Workers? London, UCL Press. pp 9-44 
Michel, S. (1998) Childcare and Welfare (In)justice, Feminist Studies 24, 1, 44-54.

Mink, G. (1998) The Lady and the Tramp (II): Feminist Welfare Politics, Poor Single Mothers and the Challenge of Welfare Justice, Feminist Studies 24, $1,55-64$.

Morgan, P. (1996) Who Needs Parents? The effects of childcare and early education on children in Britain and the USA London, IEA Health and Welfare Unit.

Pascall, G. (1997) Social Policy: A New Feminist Analysis London, Routledge.

Peng, I. (1997) Single Mothers in Japan: Single Mothers who Work, in S. Duncan and R. Edwards (eds) Single Mothers in an International Context: Mothers or Workers? London, UCL Press. pp 115-148.

Sainsbury, D. (1996) Gender, Equality and Welfare States Cambridge, Cambridge University Press.

Spicker, P. (1991) Solidarity, in G. Room (ed) Towards a European Welfare State? Bristol, SAUS.

Waldfogel, J. (1996) What do We Expect Lone Mothers to do? Competing Agendas for Welfare Reform in the United States Discussion Papers WSP/124, Welfare State Programme, London, LSE/ STICERD.

\author{
Author \\ Celia Briar is a Senior Lecturer, \\ Department of Social Policy and Social Work, \\ Massey University, \\ Private Bag 11 222, \\ Palmerston North. \\ E-mail: C.J.Briar@massey.ac.nz
}

